\title{
Wojciech Kamczyk
}

University of Silesia in Katowice

ORCID: 0000-0002-6861-7360

\section{Spiritual and Moral Implications of Baptism According to Mark the Hermit ${ }^{1}$}

\begin{abstract}
By taking up the problem of baptism in his writings, Mark the Hermit responds to the tendencies of the Messalians, who denied the value of baptism. Pointing to the consequences of the sacrament, he emphasizes its effectiveness in terms of being rescued from the corollaries of Adam's sin, restoring freedom and the ability to fulfill the commandments. He emphasizes the priority and efficacy of grace given in a secret manner at the time of baptism. He reminds, however, that baptism does not deprive man of free will, but it can support it in fulfilling the law of God. He also emphasizes the mysterious indwelling of the entire Holy Trinity in the heart of the baptized and its activity. For Mark the Hermit baptism itself also involves "being placed in the paradise of the Church," which he understands as the ability to perform acts of love towards one's brothers.
\end{abstract}

Keywords: Mark the Hermit, Messalianism, baptism, effects of baptism, God's law, Church, morality, free will

Wessalianism was spreading, a doctrine that accentuated the

${ }^{1}$ This article is a translation of the article originally published in Polish: Wojciech Kamczyk, "Duchowe i moralne implikacje chrztu według Marka Eremity," Collectanea Theologica 89 (2019) no. 1, 15-32. Translated from Polish by Maciej Górnicki.

${ }^{2}$ Mark the Hermit, also known as Mark the Monk, was a pupil of John Chrysostom and the contemporary of Nilus the Ascete and Isidore of Pelusium. He was probably the abbot of the monastery in Ancyra, later he led an ascetic life in the Judean Desert, and left behind several writings, mainly on ascetic and theological subjects 
importance of mystical experiences and indirectly degraded the importance of the sacraments, including baptism, as having no effective power to free man from sin. Proponents of Messalianism believed that only intense prayer is capable of casting out Satan, who, as a result of Adam's sin, lives in every human being since birth. Although they did not reject the possibility of forgiving sins, they believed that baptism was not capable of removing the very "root of evil" that Adam's sin brought about. ${ }^{3}$

Mark the Hermit did not remain silent in the face of the unorthodox currents of his era. ${ }^{4}$ It is therefore worth looking at his teaching on the consequences of baptism, both internal and spiritual, as well as more external, which translate into the moral life and behaviour of the baptised. Since one of the most serious errors of Messalianism at the time was to deny the value of baptism, it will be interesting to see how Mark justifies its importance and what role he attributes to human experience and efforts in this regard.

\section{Baptism and "Adam's Sin"}

The first 'group' of the consequences of baptism, of which Mark the Hermit speaks, is related to the "sin of Adam" which man

(cf. J. Quasten, Initiation aux Pères de l'Église, Paris 1963, p. 705; P. Szczur, "Marek Eremita," in: Encyklopedia Katolicka, vol. 11, Lublin 2006, col. 12771278).

${ }^{3}$ Cf. J. Misiurek, "Mesalianizm,” in: Encyklopedia Katolicka, vol. 12, Lublin 2008, col. 589-590; A. Guillaumont, Modlitwa ustawiczna czy też wytaczność modlitwy: messalianie, transl. L. Balter, "Communio" 5(1985), vol. 4, p. 118; A. Bober, "Asceza - uczłowieczenie czy odczłowieczenie w świetle źródeł wczesnego chrześcijaństwa," in: Asceza - odczłowieczenie czy uczłowieczenie, red. W. Słomka, Lublin 1985, p. 109; J. Quasten, Initiation aux Pères de l'Église, Paris 1963, p. 707.

${ }^{4}$ Cf. B. Peterson, Die Schrift des Eremiten Marcus über die Taufe und die Messalianer, "Zeitschrift für die Neutestamentliche Wissenschaft" 31 (1932), p. 273; J. Gribomont, Marc l'Ermite et la chrystologie évagrienne, "Cristianesimo nella storia" 3 (1982), p. 77. 
inherited from his ancestors, also known as inherited $\sin .^{5}$ The effect of baptism is to overcome the sin originating with the ancestors ${ }^{6}$ :

The one who was worthy of dying was once, according to the law, for all of them, sentenced to death. He who lives by faith, lives in view of repentance, but even if it does not result from our own sin, but from inherited sin, [then] being baptized, we have been cleansed, and being cleansed, we have received commandments. ${ }^{7}$

This statement comes from the work On Penance, in which the problem of the sensibility of penance is analysed. On this occasion, Mark the Hermit notes that baptism, as unique and once in a lifetime, has a purifying character. This purification applies to every sin, not only the one that comes out of man's own fault, but also inherited sin. It is complete, full and one-off, and it draws its effectiveness from the one and only death of Jesus for sins. Since the purification is complete, there remains no "root of sin," as the Messalians would have it, no debt to pay for the gates of the kingdom of heaven to be opened, and the need for repentance stems from the need to realize, after baptism, the doctrine of Christ, who called just as much for conversion and acceptance of baptism as for repentance. ${ }^{8}$

For this reason Mark also sometimes calls baptismal purification liberation. In this way he shows another aspect of the consequences of baptism:

If, in spite of our baptism, we have not been liberated from inherited sin, then it is obvious [that] we are also unable to

\footnotetext{
${ }^{5}$ The terminology used by St Mark does not use the term "original sin," but only "inherited sin" or "Adam's sin." This is partially because contemporary theology is based on the teaching of St. Augustine, who was basically contemporary to Mark the Hermit, but practically unknown in the East; cf. H. Pietras, Poczatki teologii Kościoła, Kraków 2000, p. 298-305; J.N.D. Kelly, Początki doktryny chrześcijańskiej, transl. J. Mrukówna, Warszawa 1988, p. 259-273.

${ }^{6}$ English translations of Mark the Hermit's texts after the Polish version.

${ }^{7}$ Mark the Hermit, De paenitentia XII, 5-9, SCh 445, p. 252: “"А $\pi \alpha \xi$ ó oै $\xi 10 \varsigma$

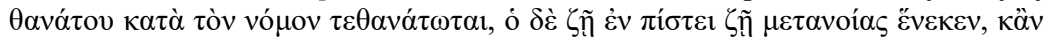

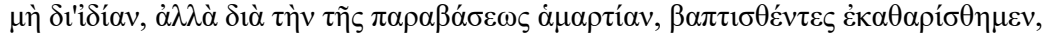

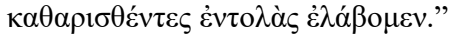

${ }^{8}$ Cf. Mark the Hermit, De paenitentia XII, 4-5, SCh 445, p. 252.
} 
fulfil the works of freedom. If, on the contrary, we have been able to do so, then it is also obvious that we have been freed from the bondage of $\sin ^{9}{ }^{9}$

For Mark, baptism is liberation, but not only in the sense of purification itself. Baptism gives freedom from that primordial evil that has occurred in every human being because of Adam's sin. Liberation here means being able to act as a free man. Liberation from the slavery of sin means not being compelled to do evil, cancelling a certain "ill-fate" that makes us doomed to behave wrongly. ${ }^{10}$

It should be noted, however, that Mark emphasises that baptism does not free us from the predilection for sin, the predilection for not keeping the commandments, which we also inherited from Adam. What is important here is a distinction that our author explains accurately and precisely: we did not inherit the impossibility of keeping the commandments, but only a certain tendency to avoid observing them. Our will has remained intact and is also not affected by baptism, although it strengthens the will and helps to combat this inherited tendency. ${ }^{11}$

Mark explains this issue in the following way:

Man is liberated from the point of view of the gift of Christ, and from the point of view of his own will where his love is, there he abides, the baptised person remains as he was, because free will cannot be forced into anything. ${ }^{12}$

\footnotetext{
9 Mark the Hermit, De baptismo II 56-60, SCh 445, p. 302-304: "Eì $\delta \dot{\varepsilon}$

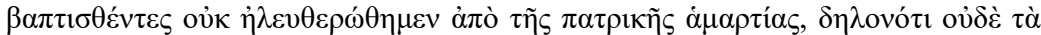

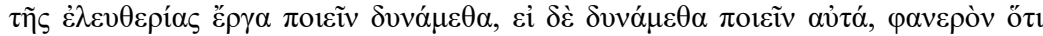

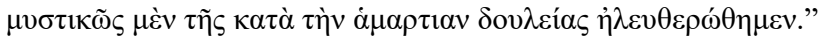

${ }^{10}$ Cf. B. Peterson, Die Schrift des Eremiten Marcus über die Taufe und die Messalianer, "Zeitschrift für die Neutestamentliche Wissenschaft" 31 (1932), p. 276.

${ }^{11}$ Cf. Mark the Hermit, De baptismo XII, 5-14, SCh 445, p. 372.

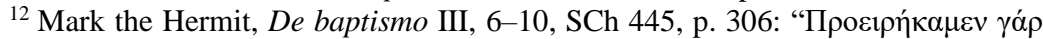

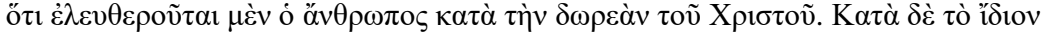

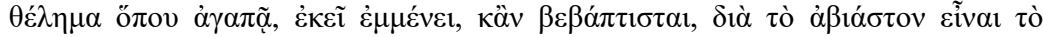

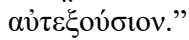


This freedom is received as a gift from Christ himself and, as such, this gift is effective in itself, complete and full. Under no circumstances, however, does baptism affect the free will of man, which retains its properties, remains independent and capable of love. ${ }^{13}$ Baptism does not automate the fact of salvation in man; it is necessary, but not sufficient for salvation. For its value to be realised and fulfilled, the cooperation of man's free will is necessary fulfilling the commandments. Mark repeatedly stresses and supplements this issue. ${ }^{14}$ Being freed from sin and its influence does not put one on the path of "inability" of $\sin .{ }^{15}$

However, also in this respect man can count on grace, which was granted at the moment of baptism. Mark writes:

Understand that the grace of help in temptation does not come to you from outside, but has been given to you secretly through baptism, and works in you to the exact extent [with the power] that you turn away from bad thoughts ${ }^{16}$.

According to Mark, even though baptism takes away personal sins and frees one from "Adam's sin," it does not deprive one of the freedom of choice and therefore of the possibility of falling and sinning again. This situation is exploited by the devil, exposing the baptised person to what is known as bad thoughts or simply temptations. ${ }^{17}$ For the ancient people these thoughts, because they

\footnotetext{
${ }^{13}$ Mark the Hermit probably refers here to specific beliefs about the properties of the will, its "abiding place", which is probably the reason for the belief that love is the result of decisions.

${ }^{14}$ Cf. Mark the Hermit, De baptismo V,114-119, SCh 445, p. 334.

15 The Messalians denied the value of baptism, and the liberation from passion was to be brought about by intense and constant prayer, allowing the "sensation" of the Holy Spirit. It was irrelevant and even unworthy of a "spiritual" man to take up physical work or any other activity commonly considered useful. Cf. J. Misiurek, "Mesalianizm," in: Encyklopedia Katolicka, vol. 12, Lublin 2008, col. 589-590.

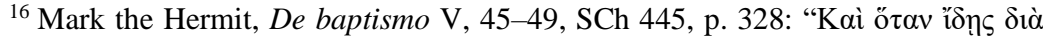

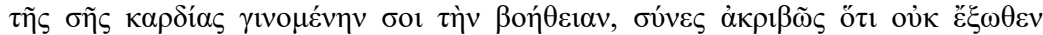

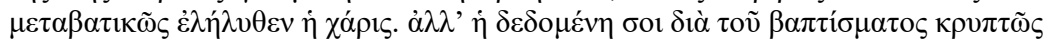

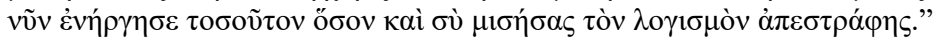

${ }^{17}$ Cf. Mark the Hermit, "De lege spirituali" 93-97, SCh 445, p. 96-98, transl. A. Jasiewicz, in: Święty Marek Mnich, O prawie duchowym, "Śląskie Studia Historyczno-Teologiczne" 45,2 (2012), p. 266.
} 
were disturbing, gave birth to negative feelings, were sometimes understood as synonymous with lust, sin and evil. ${ }^{18}$ For Mark, however, temptations alone, hated by man, even when they begin to rule in the human mind, are by no means the legacy of Adam's sin, but the result of our infidelity after baptism. ${ }^{19}$

Although man is still subjected to temptations, in baptism he receives a gift making it possible to resist them. The temptation itself is not sin and this is precisely and strongly emphasised by Mark the Monk, who also assures that God in this situation does not leave man alone. It is exactly at the moment of baptism, in a way not perceptible for the baptised person, hiding its presence from sensations, ${ }^{20}$ that a grace was granted which supports one in temptations, helps to reject them and not to give oneself to bad thoughts. Mark even teaches that when man has removed all deliberate evil from his mind, struggle with temptations becomes easier or even predictable. ${ }^{21}$

The grace to reject temptations does not come from outside, it is not a grace given at a given moment, but a habitual gift, a certain capacity placed at the time of baptism, a gift closely related to it, which is activated at certain moments of trial. ${ }^{22}$ Certainly for this reason, too, Mark claimed that temptation itself should be treated not as coming from outside, but as one's own stirring. ${ }^{23}$ One should not imagine that the effects of Adam's sin were avoided by the grace of

${ }^{18}$ Cf. T. Špidlík, I. Gargano, V. Grossi, “Duchowość Ojców Kościoła,” in: Historia duchowości, vol. 3, Kraków 2004, p. 60.

${ }^{19}$ Cf. Mark the Hermit, De baptismo III, 72-75, SCh 445, p. 312.

${ }^{20} \mathrm{Cf}$. Diadochus of Photike, Capita centum de perfectione spiritali 77, SCh 5bis, Paris 1955, p. 135; T. Špidlík, I. Gargano, V. Grossi, "Duchowość Ojców Kościoła," in: Historia duchowości, vol. 3, Kraków 2004, p. 60.

${ }^{21}$ Cf. Mark the Hermit, De lege spirituali 139, SCh 445, p. 110, transl. A. Jasiewicz, in: Święty Marek Mnich, O prawie duchowym, "Śląskie Studia HistorycznoTeologiczne" 45,2 (2012), p. 268.

${ }^{22}$ Cf. T. Špidlík, I. Gargano, V. Grossi, "Duchowość Ojców Kościoła,” in: Historia duchowości, vol. 3, Kraków 2004, p. 60.

${ }^{23}$ This does not mean at all that Marek believed that temptation is indeed what is born in and comes from man, but his advice was to treat temptation itself, not its actual source and origin; cf. Mark the Hermit, "De lege spirituali" 165, SCh 445, p. 116, transl. A. Jasiewicz, in: Święty Marek Mnich, O prawie duchowym, "Śląskie Studia Historyczno-Teologiczne" 45,2 (2012), p. 270. 
Christ, and that subsequent sins are avoided for other reasons. Sins can only be avoided as a result of God's gift, which man receives in baptism.

Mark links being cleansed and liberated from sin to the relationship with God:

When the first man fell, [lit. he became mortal], he consequently became a stranger to God, [lit. hidden from God], we too were not able to live in God. That is why the Lord came to give us life through the renewing [baptismal] bath and to reconcile us with God. ${ }^{24}$

Referring to the figure of the first man - Adam, Mark speak

$\mathrm{s}$ about his fall, death and becoming a stranger to God. The first feature of Adam's act, death, was his free choice. For us, his descendants, it is a necessity, we have no influence over it. ${ }^{25}$ The second feature seems to also define the essence of Adam's sin. It is precisely hiding from God, "alienation" from God that is, apart from mortality, in a sense "inherited" by all people, Adam's descendants. It results in the inability to lead one's life in God. However, the latter inability may be changed.

Baptism in this sense results in reconciliation with God, it excludes and eliminates that "alienation" of which Mark speaks. It builds a new bond with God, lost in paradise by the first parent. Baptism brings us back to life in a spiritual way, to the life we should all lead in God. ${ }^{26}$ In this sense it is also a renewal, it does not create something completely new, without precedent, but it restores the situation that existed at the beginning of creation. ${ }^{27}$

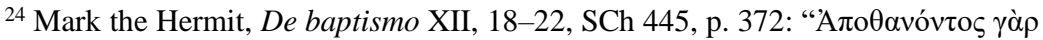

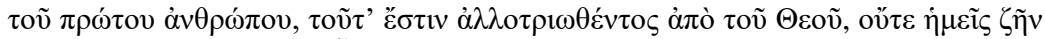

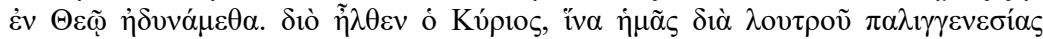

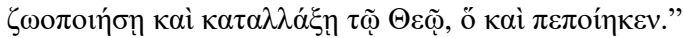

${ }^{25}$ Cf. Mark the Hermit, De baptismo XII, 24-27, SCh 445, p. 372.

${ }^{26} \mathrm{Cf}$. K. Jüssen, Dasein und Wesen der Erbsünde nach Markus Eremita, "Zeitschrift für Katholische Theologie" 62 (1938), p. 84.

${ }^{27}$ Here, Marek refers to the teaching, popular in the East, about the original happiness of man; cf. J.N.D. Kelly, Początki doktryny chrześcijańskiej, transl. J. Mrukówna, Warszawa 1988, p. 257-262.
} 
Therefore, baptism cleanses man, frees him from the slavery of sin and leads to reconciliation and closeness to God. These effects are not an experiential, perceptible consequence of the sacrament, but a grace hidden by God mysteriously in the human heart.

\section{Christ and Holy Ghost Indwelling Us}

Mark develops the issue of intimacy with God, mentioned in the previous paragraph, highlighting the problem of God indwelling in man:

It is sufficient to carefully recognize in oneself the secret presence of Christ from baptism ( $\mathrm{Col} 2: 12 ; 3: 3)$, the one that the Apostle confirms. ${ }^{28}$

According to Mark, the presence of Christ began in the baptised at the moment of baptism. It has a secret character, not manifested in any internal or even less - external way. This presence is confirmed by the Apostle Paul in his teaching. On this occasion, St Mark refers to the Letter to the Colossians, recalling the teaching on being buried with Christ in baptism and rising from the dead with Him (cf. Col 2:12) and the truth that the life of the baptised person is hidden in God (cf. Col 3:3). He is convinced that the Apostle himself, in line with the Book of Proverbs, guarded his own heart, which became God's dwelling place, because the source of life began to "beat" in him (cf. Prov 4:23) ${ }^{29}$ This "dwelling" therefore seems to be somewhat two-sided: on the one hand, it was God who dwelt in man and became the source of new life in him, and on the other hand, through baptism, man was united to God's life, thus becoming "hidden in God."

Who is it in fact that indwells man through the baptism? Mark notes:

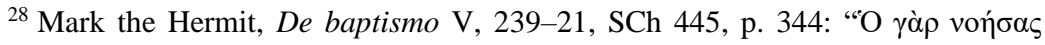

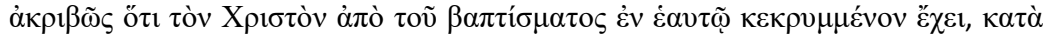

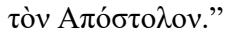

${ }^{29}$ Cf. Mark the Hermit, De baptismo V, 239-21, SCh 445, p. 344.
} 
It is the Holy Spirit who is the one we receive through baptism. But since he is called both the Spirit of God and the Spirit of Christ, this grace makes us receive, through the Spirit, the Father and the Son. ${ }^{30}$

The one who is imparted in baptism and dwells in man is above all the Holy Spirit. Mark reminds us that it is usual to call him both the Spirit of God the Father himself and the Spirit of Christ. It is a sign of faith in the Holy Trinity and the unity of Divine persons. Through him, the whole Holy Trinity dwells in man. This does not mean that the Spirit Himself is the Trinity, but that this presence results from the strict unity of Divine persons. ${ }^{31}$ Man, therefore, through baptism becomes the dwelling place of the entire Holy Trinity.

Provoked by the reasoning of some unorthodox groups and trends Mark also recalls biblical predictions concerning the promise of imparting the Holy Spirit. He stresses, however, that this indwelling of the Spirit is a gift already realized. We are unable to appreciate and feel it, because this grace is revealed differently in each person. He compares this presence to the sun, to which each person reacts differently and is impacted by it in a different way. The sun is always perfect and full of power, but not everyone benefits from it to the same degree. This is the case with the presence of the Holy Spirit in man. From the moment of baptism, He enables every believer to do every kind of act and to accept His gifts. The extent to which this is done depends on the degree to which man fulfils the commandments, lives according to Divine teaching and bears witness to his faith. ${ }^{32}$

Speaking of the Spirit of God indwelling the baptised person, Mark also evokes the simile of the temple:

Paul says that we are the temple of the Spirit and encourages us to offer [in it] spiritual sacrifices [...] and to circumcise

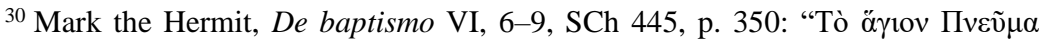

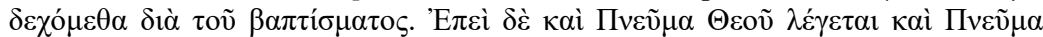

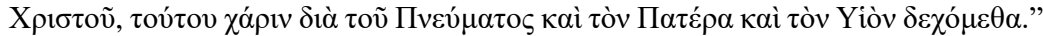

${ }^{31}$ Cf. Mark the Hermit, De baptismo VII, 5-14, SCh 445, p. 350-352.

${ }^{32}$ Cf. Mark the Hermit, De baptismo IX, 1-25, SCh 445, p. 356.
} 
our hearts not according to the letter of the law, but according to the spirit, according to the spiritual law, which the heavenly lawgiver, Jesus Christ, there [i.e. in the heart] by the power of the Spirit, writes not on tablets of stone, but on [tablets of] hearts. ${ }^{33}$

Through baptism man becomes the temple of the Holy Spirit. The very term "temple" refers here to the Jewish temple, which for the followers of Judaism was the only place where sacrifices were offered to God and where the encounter with Him took place. It was a place where the regulations of the law given by Moses were fulfilled, the law written by God himself on the stone tablets on Mount Sinai. Paul encourages to offer new, spiritual sacrifices in this temple, being the dwelling place of the Spirit. The necessity of offering these sacrifices results now not from the old, Jewish law, but from the new one, spiritual. Christ, who is a new lawgiver in the place of Moses, has written them not on stone tablets, as was the case during the Old Covenant, but on the living tablets of human hearts.

Analysing selected verses of the seventh chapter of the Letter to the Romans, Mark points to the spiritual value of baptism similar to the meaning that the Law had for the Jews:

From this comes the spiritual interpretation which [Paul the Apostle] gives of the whole of the Law: he does not want [the baptized man] to be under the Law, but under [the influence of] grace, which is the spiritual law written in us. ${ }^{34}$

According to Paul, the knowledge of the law also gave rise to the possibility of falling and sinning, which Satan took advantage of. The law, however, should not be rejected, because it is the basis of

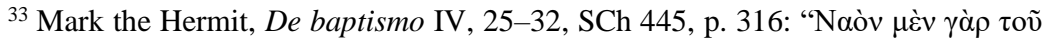

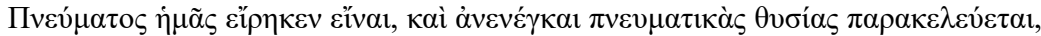

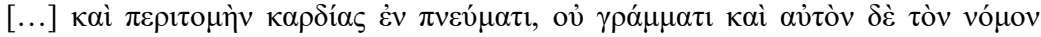

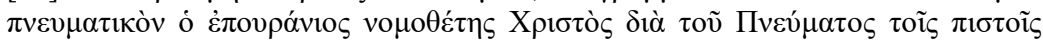

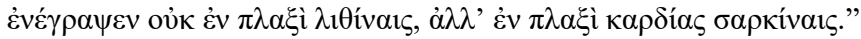

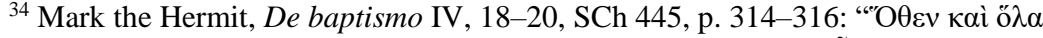

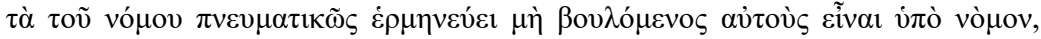

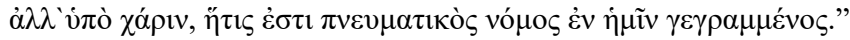


morality, knowledge of what is bad and what is good, and the basis of life for a Christian as well. This is why Mark follows the spiritual interpretation of St. Paul, indicating that through baptism, the spiritual law of grace was written in the heart of the believer. It does not exempt from observing the law of the commandments (external law), but enables us to fulfil them. Thanks to the grace of baptism, a spiritual law is written in the heart of a person, the same one about which St. Paul speaks, using the simile of the temple.

Mark, especially in the work De lege spirituali, points out that Christian freedom is a certain obedience to Christ and his "law of freedom." The Kingdom of Heaven is a gift, not a reward for deeds. ${ }^{35}$ The essence of this "spiritual law" is not achieving perfection, because perfection itself is hidden in Christ's Cross. The law is fulfilled by the true knowledge and observance of the commandments (doctrine) and by the grace of Christ himself. It is infallible, and it helps to find the true good in keeping the commandments. It also makes us understand that we cannot become perfect without God's gifts. ${ }^{36}$

In order to deepen this teaching and explain it further, Mark also teaches about the heavenly Jerusalem where the baptised is placed. He does this in response to allegations that the biblical allusions to the heavenly Jerusalem refer only to eschatological reality. He compares the effects of baptism to "climbing Mount Zion, the city of the living God, the heavenly Jerusalem" mentioned in the Letter to the Hebrews. Christ is the one who entered there first for the sake of man. Mark stresses that we did not enter our own place and neither did we do it for ourselves, but that we "entered" a certain "place," a certain reality of God's presence - Jesus. Entering this reality means being able to receive all the spiritual gifts that are associated with it, even if they do not manifest themselves externally. All these gifts are received by man starting with baptism in a perfect but secret way. They remain hidden, however, if a person

${ }^{35}$ Cf. A. Jasiewicz, Święty Marek Mnich, O prawie duchowym. Wstęp, "Śląskie Studia Historyczno-Teologiczne" 45,2 (2012), p. 258.

${ }^{36}$ Cf. Mark the Hermit, "De lege spirituali" 28-31, SCh 445, p. 82, transl. A. Jasiewicz, in: Święty Marek Mnich, O prawie duchowym, "Śląskie Studia Historyczno-Teologiczne" 45,2 (2012), p. 262. 
lacks faith, if he does not open up to them with his life according to the commandments. ${ }^{37}$

Baptism therefore gives a certain capacity to achieve perfect love, but it is only used by those who, as it were, die for themselves, go beyond any thoughts that might separate them from Christ and His love. Giving the example of St. Paul and His teaching as an example, Mark reminds us that there is no power that could separate us from the love of Christ, ${ }^{38}$ for this bond stems from baptism, not from human experiences.

Being introduced into the temple is therefore a symbol of baptism and entering the path of a new relationship with God, based not only on the regulations of law and norms, but above all having the spiritual law of love as the foundation.

\section{3. "The Paradise of the Church"}

Mark deepens his teaching using another simile:

The Lord came because of us, he died for us and freed us from the death inherited from our ancestors, he cleanses us and renews us by baptism, places us in the paradise of the Church and allows us to eat of all the fruit that is in that paradise, that is to say love everyone whoever has been baptized in this Church, patiently endure faults, not to seek [the opportunity] to catch others in the act of unfaithfulness, not to love only those who seem good to us, while rejecting those we think are bad. ${ }^{39}$

Mark links the effectiveness of baptism to the coming of Christ, to the mystery of incarnation and redemption. Christ in baptism not

\footnotetext{
${ }^{37}$ Cf. Mark the Hermit, De baptismo VIII, 5-20, SCh 445, p. 352-354.

${ }^{38}$ Cf. Ibid., 21-39, SCh 445, p. 354.

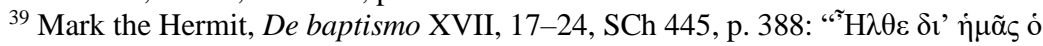

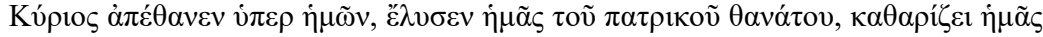

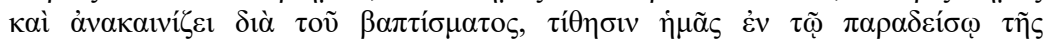

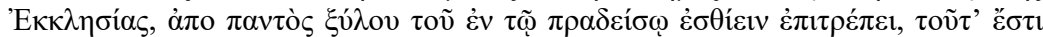

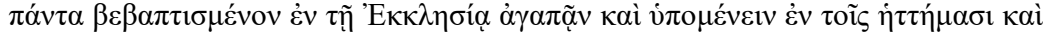

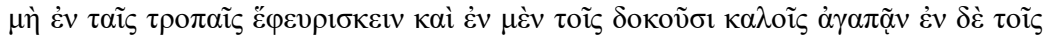

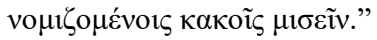


only frees us from the death inherited from our ancestors, not only cleanses and renews us, but also "places us in the paradise of the Church." Mark refers the paradise to the community of the Church, the people baptised in it. This "placing in paradise" allows the use of all the fruit of the trees that are in this paradise, which the author refers to the commandment of love of neighbour. In reality, therefore, this "placing in paradise" is not so much a description of a formal and spiritual affiliation to the community of the baptised, but a description of the principle of life of that community, a characteristic of the moral consequence that comes out of baptism, which is the observance of the commandment of love of neighbour. The baptised person was "placed in the paradise of the Church," that is to say, he was obliged to love his neighbour, to observe the commandments and God's doctrine, which guards that love.

Mark makes his reflection more concrete by talking about enduring vices patiently, not looking for opportunities to catch anybody red-handed, that is - sinning, as well as not favouring only those who are loved, who seem the only ones that are good, and rejecting those who seem bad. "Being placed in the paradise of the Church" should result in its members relating to each other not on the basis of mutual law-focused coercion (laws, regulations, procedures) and denunciation, but on the basis of love and forgiveness. ${ }^{40}$ One should not be guided only by appearances, sensations, superficiality, but should go deep, in accordance with Christ's teaching.

The directive to love and forgive each other, resulting from the commandment of love, can be extended to all God's other teachings and indications:

We must believe in the preaching of the Apostles, persevere in our own tasks of faith, not compare the power of God to human capabilities, not submit ourselves again to the law of bondage, on the contrary, shape our freedom by following the commandments: according to the proportion in which the latter are fulfilled, the whole truth is discovered and, we

40 Cf. K. Fitschen, Messalianismus und Antimessalianismus. Ein Beispiel ostkirchlicher Ketzergeschichte, Göttingen 1998, p. 250. 
know this perfectly well, in proportion to how much they are rejected, we are exploited by $\sin .^{41}$

Comparing God's action to human activities can lead to misconceptions. Therefore the author pointed out that one should not put trust in one's own perception of reality, in one's own experience or thoughts, but in the teaching of the apostles. Referring to Paul's teaching on the law of freedom, he points out that in order to discover the whole truth, one must follow the path of observing the commandments. Ceasing to live according to God's teaching leads to lapsing into the slavery of sin, when we allow ourselves to be guided and manipulated by it. In the relationship between the freedom that man has received and the need to keep the commandments a right proportion must be preserved:

Ultimately, the holy baptism is perfectly efficient, but does not lead to perfection the person who does not keep the commandments. ${ }^{42}$

This is the teaching of the Holy Scripture and not just human invention. To support his thesis, Mark quotes St. Paul's thought from the First Letter to the Corinthians ${ }^{43}$ : "Christ died for our sins in accordance with the Scriptures" (1 Cor 15:3) and the Letter to the Romans: "We were buried therefore with him by baptism into death" (Rom 6:4), "For one who has died has been set free from sin" (Rom 6:7) and "sin will have no dominion over you" (Rom 6:14). This truth is confirmed by those who observe the commandments.

Baptism in its efficacy does not "compel" to salvation, but leaves freedom to follow the path of God's teaching. But without observing the teaching it loses its significance in a sense:

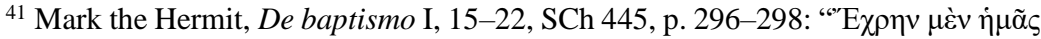

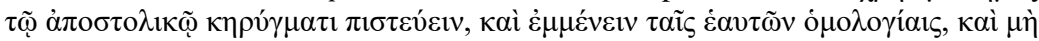

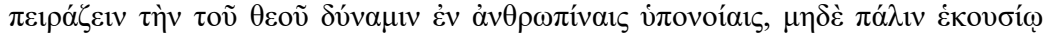

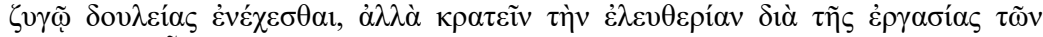

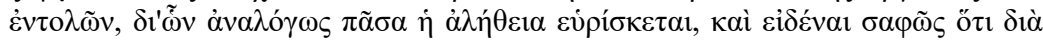

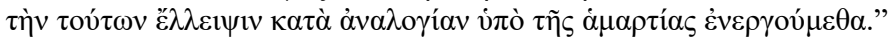

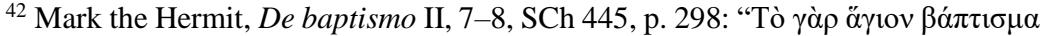

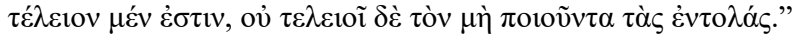

${ }^{43}$ All quotation from the New Testament after the ESV translation.
} 
Faith does not consist only in being baptised in Christ, but also in observing His commandments. ${ }^{44}$

It is the baptised person's moral duty to keep the commandments, the teachings of Christ, in whose name one was baptised. This unequivocal indication is a polemic with the Messalians, who denied the value of baptism, failing to see the need to live according to the teachings of Christ, but seeking only mystical experiences. ${ }^{45}$ Mark the Hermit points to the need to perform acts, concrete works, commandments, and to fulfil Christ's teachings as a necessary condition for sanctification and salvation. He even says that the commandments are a kind of protection of the limits of freedom that we have received in baptism.

In De paenitentia Mark, while stressing that everyone has received salvation and justification free by God's grace, also points out that they need penance. However, in itself, it has no purifying character and power, unlike baptism, as has already been presented. Penance is the fulfilment of Jesus' command related to receiving baptism and to repent. For Mark, it is closely related to the Saviour leaving the commandments, a teaching making it possible to preserve the grace of baptism. He stressed the importance of his conviction, recalling the words of Jesus himself: "whoever relaxes one of the least of these commandments and teaches others to do the same will be called least in the kingdom of heaven" (see Matt $5: 19) .{ }^{46}$

The grace granted in baptism is not lacking in any way. Even though it is imparted in a secret, non-visible way, it does not mean

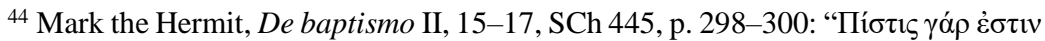

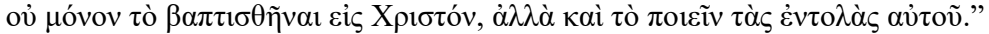

45 The Messalians refused to apply any kind of discipline to themselves and saw no need for work; they renounced material goods, dressed in ascetic clothes, wore long hair, slept in squares and streets, men together with women, supported themselves with alms, claimed to be engaged in constant prayer; cf. J. Gribomont, "Messaliens," in: Dictionnaire encyclopédique du christianisme Ancien, red. A. di Berardino, vol. 2, Paris 1990, p. 1632; A. Guillaumont, Modlitwa ustawiczna czy też wyłączność modlitwy: messalianie, transl. L. Balter, "Communio" 5 (1985), vol. 4, p. 117.

${ }^{46}$ Cf. Mark the Hermit, De paenitentia X, 24-35, SCh 445, p. 248.
} 
that it is less real and efficient, although this efficacy is not always manifested:

Grace was given secretly to those who were baptised in Christ. It acts each time in proportion to the way in which the commandments are fulfilled. Secretly, grace does not give us security, while [that security] depends on whether or not we do good as we can. ${ }^{47}$

Baptism is the fullness of a gift, but at the same time it is not its safeguard. The security of salvation depends on doing good according to human capabilities. Mark reminds us that at the time of baptism man was given not only graces that remain hidden, but many of which manifest themselves outside. All the virtues characterizing the baptised person, the powers by which he is able to fulfil the commandments and live according to God's teaching, are the result of the graces received at the time of baptism. Once again, Mark goes in the direction of opposing unorthodox currents, stating that none of the baptised can say that he has done any good through his own power, strength, and abilities. ${ }^{48}$ He reminds us that grace is full and complete:

Every person baptised in orthodoxy has secretly received the fullness of grace, but has also received full protection in the form (in function) of his observance of the commandments. ${ }^{49}$

The function of keeping the commandments, ensuring the "security" of salvation, is also inscribed in the grace of baptism. This "protection," however, depends on man's involvement in following God's teachings. But, according to our author, the mere fulfilment

\footnotetext{
${ }^{47}$ Mark the Hermit, De his qui putant se ex operibus iustificari 56, SCh 445, p. 146:

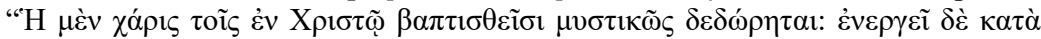

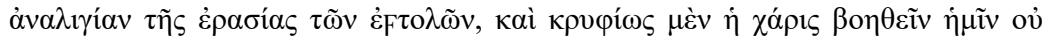

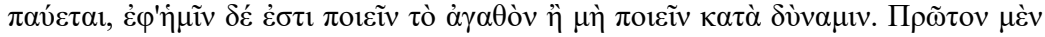

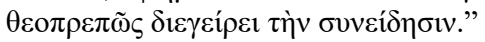

${ }^{48}$ Cf. Mark the Hermit, De baptismo V, 226-230, SCh 445, p. 344.

${ }^{49}$ Mark the Hermit, De his qui putant se ex operibus iustificari 85, SCh 445, p. 156:

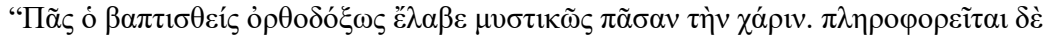

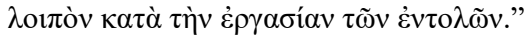


of the commandments and penance do not make much sense when they do not result from the grace and gift of God.

"Dwelling in the paradise of the Church" is therefore a call to the baptised person to live according to God's teaching, according to the commandments. This is the meaning of the spiritual law written in the heart of man. The observance of the commandments, although it does not in itself open up the kingdom of heaven, is nevertheless given by baptism a "protective" function towards the grace of purification, freedom and reconciliation with God which the baptised person receives in this sacrament. Proportionately to man's involvement, it produces effects in his life and allows the secret graces granted in baptism to manifest themselves.

\section{Conclusion}

Mark presents the consequences of baptism for the baptised person in opposition to the Messalians. Baptism cleanses from the sin inherited from the first parents and from all the other ones committed by man. It liberates from sin not only in the sense of purification itself, but also from a certain "compulsion" of disobedience to the commandments - it leaves this matter to man's free will, which is does not disturb. Finally, it leads to man's reconciliation with God, eliminating a certain "alienation" that has occurred in the mutual relationship.

The positive consequence of baptism is God's indwelling man. Mark speaks first of all of the presence of the Holy Spirit, but he notes that it is also the presence of the whole Trinity, and therefore also of the Father and the Son. This presence is secret, mysterious, imperceptible in the sphere of emotions and impressions, but real. It is not only a promise, an element of the future, but a gift already realised. It is similar to God's presence in the Jewish temple, where the provisions of Jewish law were fulfilled through appropriate sacrifices. However, on the tablet of the baptised person's heart, the spiritual law of grace has been written, whose fruitfulness is realized through the spiritual law and the observance of the commandments.

Next, baptism results not only in personal cleansing and reconciliation, but also in the incorporation into the community of believers, "it places one in the paradise of the Church." For Mark, 
however, this does not mean merely a formal act, but an invitation and a moral call to live according to God's teaching. This approach to understanding the effects of baptism and the nature of the Church shows the life of a Christian on the one hand as a gift of God's grace, free and undeserved and on the other one points to a certain moral obligation, which results from baptism. The commandment of love of one's neighbour can of course be cited in the first place, but on the basis of the statements made by Mark Monk earlier, it can clearly be extended to the observance of the commandments and God's teaching in general. Living according to the commandments is not, therefore, an absolute condition of salvation, but is a moral obligation that comes out of baptism. It also has a "protective" function, safeguarding against wasting and losing the grace of salvation received in baptism.

Mark the Hermit's conception, although so distant in time and mentality, remains valid until now. It indicates not only the theological and spiritual aspects of baptism, but also makes us realize the need for effort on the part of man who receives grace and the need for constant cooperation with the One who grants it. 